\title{
MULTI-OBJECTIVE OPTIMIZATION TO DETERMINE THE COLD DRYING MODE OF GAC (MOMORDICA COCHINCHINENSIS SPRENG)
}

\author{
Nguyen Tan Dzung ${ }^{1 凶}$, Nguyen Dang My Duyen ${ }^{1}$, Do Thuy Khanh Linh ${ }^{1}$ \\ ${ }^{I}$ Department of Food Technology, Faculty of Chemical and Food Technology, HCMC University of Technology and \\ Education, No 01-Vo Van Ngan Street, Thu Duc District, Ho Chi Minh City, Vietnam.

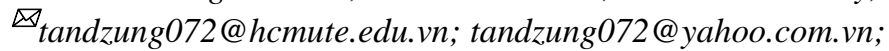 \\ https://doi.org/10.34302/crpjfst/2020.12.3.2 \\ Article history: \\ Received: \\ 8 March2020 \\ Accepted: \\ 25 July 2020 \\ Keywords: \\ Optimization; \\ multi-objective optimization, \\ cold drying; \\ Gac; \\ the cold drying process of Gac.

\section{ABSTRACT} \\ The establishment of the cold drying mode of Gac was based on the \\ solution to multi-objective optimization problem by the restricted area \\ method. Experiments were carried out to set up the mathematical model of \\ objective functions describing the influence of technological factors \\ (temperature of moisture condensation, temperature of cold drying \\ chamber, velocity air (or drying agents) and time of cold drying) in the \\ cold drying process. The restricted area method with $\mathrm{R}^{*}(\mathrm{Z})$ optimal \\ combination criterion was applied to solve the multi-objective optimization \\ problem, determining the optimal technological mode of cold drying \\ process (correspondingly $9.83^{\circ} \mathrm{C} ; 44.18^{\circ} \mathrm{C} ; 3.46 \mathrm{~m} / \mathrm{s}$ and $12.36 \mathrm{~h}$ ) in order \\ that the objective functions reached the minimum value in terms of the \\ finished product, including the energy consumption of $2.17 \mathrm{kWh} / \mathrm{kg}$, the \\ residual water content of $7.45 \%$, the anti-rehydration capacity of $8.69 \%$, \\ and the loss of total $\beta$-carotene and lycopene in Gac of $5.04 \%$.
}

\section{Introduction}

Gac is a fruit rich in carotenoid, lycopene which belong to group vitamin $A$. The $\beta$ carotene and lycopene in Gac oil are higher twice more than liver mackerel and about 10 times more than carrots (Apinya Bhumsaidon, et al., 2016). Gac is a valuable fruit in the world because it only distributes in Southeast Asia and Southern China. Many studies confirmed the valuable nutriment of Gac (Anh Le, et al., 2018; A. L. Chai, et al., 2018) such as $\beta$ carotene, lycopene, vitamin E, Q, carbohydrates, unsaturated fatty acids, amino acids, mineral, and other microelements for human. The water content of Gac is $74.6 \%$. Currently, Gac has not been popularly used like other fruits, and important nutritional sources of Gac have been untapped effectively (Betty K, et al., 2004; Anh V. Le., et al., 2018). The question is to find methods for processing and preservation of Gac to create valuable products (Haugvalstad. G. H., et al., 2005).
If Gac is dried for preservation purpose by conventional drying method, Gac can be completely destroyed its nutrients because this method is usually carried out at high temperatures (above $100^{\circ} \mathrm{C}$ ) (Heldman D. R, et al., 1992). If preservation of $\mathrm{Gac}$ is carried out at low temperature and low pressure (under points $\mathrm{O}\left(4.58 \mathrm{mmHg} ; 0.0098^{0} \mathrm{C}\right)$ by the freeze drying method, it can be completely kept natural characteristics of material (Khalloufi S, et al., 2004; Figura LO, et al., 2007) and the quality of products are very good. However, this method is not used widely because of high energy consumption (Dzung N.T, 2016c \& 2018c; Dzung N.T, et al., 2018a \& 2018b). Therefore, the application of cold drying technology for processing and preservation of $\mathrm{Gac}$ is potential method.

There have been a number of researches on establishing and solving the mathematical models of heat and mass transfer for the cold drying applied to many different types of 
drying materials, which results in the determination of the kinetics of the cold drying process (Fortes, M., et al., 1999; Gebhart B., 1992). One of the most typical model was the one of Luikov A.V. (1972), from which Holman J., (1992), Vaccarezza.L.M. et al. (1994), they achieved the mathematical models of heat and mass transfer for the cold drying of specific drying materials. Mainly in these researches the kinetics of the cold drying process was focused to establish the technological parameters, but the assessment of the qualified products via the cold drying mode reaching the objectives such as minimum energy consumption or residual water content or the anti-rehydration capacity or the loss of total $\beta$-carotene and lycopene in Gac of finished products still remained unsolved (Khalloufi S, et al., 2004; Haugvalstad. G. H., et al., 2005; Figura LO, et al., 2007). The combination of those targets with the determination of the cold drying mode is the problem of multi-objective optimization. However, it is complicated to give an answer to the multi-objective optimization problem. As always, test of the multi-objective optimization problem is a set of optimal Pareto test, each application of different methods will give different optimal Pareto tests. There are currently numerous methods applied to this problem, namely linear combination (Dzung N.T, et al., 2016a), fuzzy data classification and Harrington method (Dzung N.T, 2016c), which reveal the subjective concept of the expert group on deciding the importance of each objective function. Therefore, the utopian point method $S(Z)$ or the restricted area method $\mathrm{R}^{*}(\mathrm{Z})$ based on Pareto optimization theory is necessarily replaced to obtain the results more objective (Dzung N.T, et al., 2016b).

According to Dzung et al., (2016a \& 2016 b), it is obvious that cold drying is a complicated technique because of depending on various technological factors. The determination of cold drying mode required the outputs to reach the minimal level (Fig. 1), including the energy consumption per weight $\left(\mathrm{y}_{1}, \mathrm{kWh} / \mathrm{kg}\right)$, the residual water content $\left(\mathrm{y}_{2}\right.$,
$\%)$, the anti-rehydration capacity $\left(\mathrm{y}_{3}, \%\right)$ and the loss of total $\beta$-carotene and lycopene in Gac $\left(\mathrm{y}_{4}, \%\right)$ of the cold-dried product (finished product). It should be emphasized that those 4 outputs were affected by the 4 technological factors: temperature of moisture condensation $\left(\mathrm{Z}_{1},{ }^{0} \mathrm{C}\right)$, temperature of cold drying chamber $\left(\mathrm{Z}_{2},{ }^{0} \mathrm{C}\right)$, velocity drying agents $\left(\mathrm{Z}_{3}, \mathrm{~m} / \mathrm{s}\right)$ and time of cold drying process $\left(Z_{4}, h\right)$.

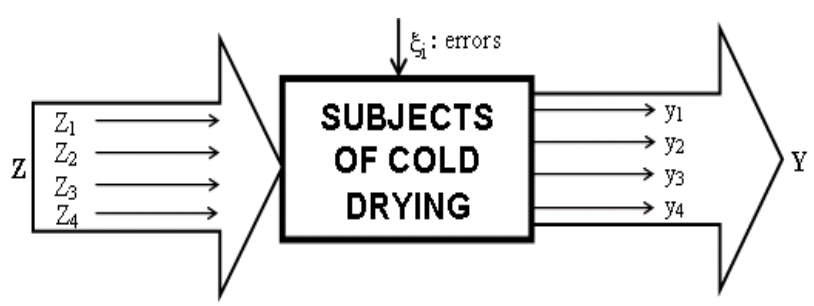

Figure 1. Diagram of cold drying subjects

However, the simultaneous consideration of all these outputs above to reach the minimal level resulted in the standard solution to multiobjective optimization problem (Dzung N.T, et al., 2011). This problem regularly appears in reality and in different fields. The answer to the multi-objective optimization problem was found in the case of the application of the $\mathrm{R} *(\mathrm{Z})$ optimal combination criterion (also known as the restricted area method) for the cold drying process of Gac. The multi-objective optimization results were used to establish the technological cold drying mode of Gac which was the closest to the utopian point but the furthest from the restricted area C, (Dzung N.T, et al., 2016a).

\section{The fundamentals in multi-objective optimization}

\subsection{Basic concepts}

The technological subjects including $\mathrm{m}$ objective functions $f_{1}(Z), f_{2}(Z), \ldots, f_{m}(Z)$ form the vector of these functions $f(Z)=\left\{f_{j}(Z)\right\}=$ $\left\{f_{1}(Z), f_{2}(Z), \ldots, f_{m}(Z)\right\}$, where $j=1$ to $m$. Every objective function $f_{j}(Z)$ is affected by $n$ variables $Z_{1}, Z_{2}, \ldots, Z_{n}$ which form the $Z$ variable vector $Z=\left\{Z_{i}\right\}=\left(Z_{1}, Z_{2}, \ldots, Z_{n}\right)$, where $i=1$ to $n$. These variables vary in the identified domain $\Omega_{\mathrm{Z}}$ and the function values 
form the domain of the objective function $\Omega f$ (in the two-objective optimization problem, the domain can be performed geometrically in the closed curve A-f(ZS)-f(Z)-B-N-M (Fig. 2), (Dzung N.T, et al., 2011).

Every objective function $f_{j}(Z)$ with $Z$ variable vector $\mathrm{Z}=\left\{\mathrm{Z}_{\mathrm{i}}\right\}=\left(\mathrm{Z}_{1}, \mathrm{Z}_{2}, \ldots, \mathrm{Z}_{\mathrm{n}}\right)$, where $\mathrm{i}=1$ to $\mathrm{n}$, is considered as the oneobjective optimization problem. Hence, the mobjective optimization problem can be simply transformed into the problem to find the minimum value for the set of $m$ one-objective optimization problems (Dzung N.T, et al., 2011):

$$
\begin{array}{r}
f_{j \min }=f_{j}\left(Z_{1}{ }^{j o p t}, Z_{2}{ }^{j o p t}, \ldots, Z_{n}{ }^{j o p t}\right) \\
=\operatorname{Min} f_{j}\left(Z_{1}, Z_{2}, \ldots, Z_{n}\right)
\end{array}
$$

$$
\mathrm{Z}=\left\{\mathrm{Z}_{\mathrm{i}}\right\}=\left(\mathrm{Z}_{1}, \mathrm{Z}_{2}, \ldots, \mathrm{Z}_{\mathrm{n}}\right) \in \Omega_{\mathrm{Z}}
$$

$$
\text { Where } \mathrm{j}=1 \text { to } \mathrm{m} ; \mathrm{i}=1 \text { to } \mathrm{n}
$$

The utopian plan and the utopian effect [1, 10]: If the variable vector $\mathrm{Z}^{\mathrm{UT}}=\left\{\mathrm{Z}_{\mathrm{i}}^{\mathrm{UT}}\right\}=\left(\mathrm{Z}_{1}{ }^{\mathrm{UT}}\right.$, $\left.\mathrm{Z}_{2}{ }^{\mathrm{UT}}, \ldots, \mathrm{Z}_{\mathrm{n}}{ }^{\mathrm{UT}}\right) \in \Omega_{\mathrm{Z}}$ is the test for all oneobjective optimization problems $(1)+(2)+(3)$, it means that $\mathrm{Z}_{\mathrm{i}}^{\mathrm{UT}}=\mathrm{Z}_{\mathrm{i}}^{\text {jopt }}$ with $\mathrm{i}=1$ to $\mathrm{n}$. Thus, $\mathrm{Z}_{\mathrm{i}}^{\mathrm{UT}}$ is called the utopian plan or the utopian test of the m-objective optimization problem.

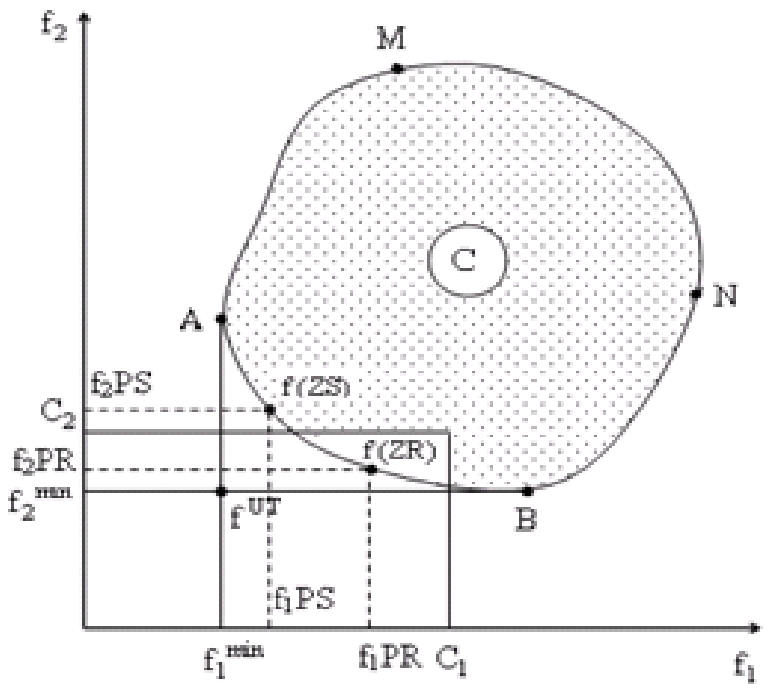

Figure 2. Dimension of objective functions of the two-objective optimization problem
In reality, $\mathrm{Z}_{\mathrm{i}}^{\mathrm{UT}}$ does not usually exist because it cannot satisfy all of the targets. However, every one-objective optimization problem $(1)+(2)+(3)$ has its own $f_{j} m i n$ (with $j$ $=1$ to $\mathrm{m})$ respectively so $\mathrm{f}^{\mathrm{UT}}=\left(\mathrm{f}_{1 \mathrm{~min}}, \mathrm{f}_{2 \mathrm{~min}}, \ldots\right.$, $\left.f_{m m i n}\right)$ does exist. Then, $f^{U T}=\left(f_{1 \min }, f_{2 m i n}, \ldots\right.$, $\left.f_{m m i n}\right)$ is called the utopian effect or the utopian point. According to Fig 2, the utopian point $\mathrm{f}^{\mathrm{UT}}$ of the two-objective optimization problem exists but lies outside the identified domain $\Omega_{\mathrm{f}}$, i.e. the utopian test does not exist.

The dominant plan and the dominated plan $[1,10]$ : It is assumed that there are two variable vectors $Z Q=\left\{Z_{i}\right\}$ and $Z V=\left\{Z V_{i}\right\}$ with $i=1$ to $\mathrm{n}$. Then, there exist respectively two function vectors $f(Z Q)=\left\{f_{j}(Z Q)\right\}$ and $f(Z V)=\left\{f_{j}(Z V)\right\}$ with $\mathrm{j}=1$ to $\mathrm{m}$.

If with all $j: f_{j}(Z Q)<f_{j}(Z V), Z Q$ is called the dominant plan (or the dominant test) over $\mathrm{ZV}$, symbolizing: $\mathrm{ZQ}$ ' $>$ ' $\mathrm{ZV}$; and $\mathrm{ZV}$ is called the dominated plan (or the dominated test), symbolizing: ZV ' $<$ ' ZQ,

The optimal Pareto plan (Dzung N.T, et al., 2011): The ZP plan is called the optimal Pareto plan in condition that ZP cannot be dominated by any other plans dependable on the identified domain $\Omega_{Z}$. Then, $f(Z P)$ would be called an optimal Pareto effect in the set of the optimal Pareto effects $\Omega_{\mathrm{f}} \mathrm{P}$. Fig 2 performs the set of the optimal Pareto effects $\Omega_{\mathrm{f}} \mathrm{P}$ as the curve A $\mathrm{f}(\mathrm{ZS})-\mathrm{f}(\mathrm{Z})-\mathrm{B}$.

Theorem 1 (Theorem Pareto): If the multiobjective optimization problem has the test which is the so-called optimal one according to some definition, this test received has to be the optimal Pareto plan without the dependence on the chosen definition (Dzung N.T, et al., 2011).

Therefore, one test of the multi-objective optimization problem $(1)+(2)+(3)$ found by any method, to be recognized as the optimal by the method chosen, must in advance be certified as the optimal Pareto plan.

\subsection{Multi-objective optimization by the utopian point method (UPM)}

Considering the m-objective optimization problem $(1)+(2)+(3)$ : The optimal values $\mathrm{f}_{1 \text { min }}, \mathrm{f}_{2 \mathrm{~min}}, \ldots, \mathrm{f}_{\mathrm{mmin}}$ can be determined after 
solving each problems, and the fact that the utopian test (the test for the whole system) does not exist still identifies the utopian point $\mathrm{f}^{\mathrm{UT}}=$ $\left(f_{1 \text { min }}, f_{2 \min }, \quad \ldots, f_{\text {mmin }}\right)$. A $\mathrm{S}(\mathrm{Z})$ optimal combination criterion is defined by the following expression (Dzung N.T, et al., 2016b):

$$
\begin{aligned}
s(z) & =\sqrt{\left[\sum_{j=1}^{m} s_{j}^{2}(z)\right]} \\
& =\sqrt{\left[\sum_{j=1}^{m}\left(f_{j}(z)-f_{j \min }\right)^{2}\right]}
\end{aligned}
$$

It is obvious that $\mathrm{S}(\mathrm{Z})$ is the distance from $f(Z)$ to $f^{U T}$, where $s_{j}(Z)=\left|f_{j}(Z)-f_{j m i n}\right|$. Choosing $S(Z)$ optimal combination criterion as an objective function, the m-objective optimization problem are restated as: Find $\mathrm{ZS}=$ $\left(\mathrm{Z}_{1} \mathrm{~S}, \mathrm{Z}_{2} \mathrm{~S}, \ldots, \mathrm{Z}_{\mathrm{n}} \mathrm{S}\right) \in \Omega_{\mathrm{Z}}$ in order that the objective function $S(Z)$ reaches the minimum value:

$$
\begin{aligned}
& S_{\min }=S(Z S)=\operatorname{Min} S(Z) \\
&=\min \left\{\sqrt{\left[\sum_{j=1}^{m}\left(f_{j}(Z)-f_{j \min }\right)^{2}\right]}\right\} \\
& Z=\left(Z_{1}, Z_{2}, \ldots, Z_{n}\right) \in \Omega_{Z}
\end{aligned}
$$

Theorem 2: If $\mathrm{ZS}$ of the optimization problem (5) does exist, ZS is the optimal Pareto test of the m-objective optimization problem $(1)+(2)+(3)$, (Dzung N.T, et al., 2016b).

Symbol: $f(Z S)=$ fPS $=\left(f_{1} P S, f_{2} P S, \ldots\right.$, $\mathrm{f}_{\mathrm{m}} \mathrm{PS}$ ). With the utopian point method (i.e. the m-objective optimization problem converts into the $\mathrm{S}$ optimal combination criterion), the optimal Pareto test ZS will be found to have the optimal Pareto effect $f(Z S)=$ fPS closest to the utopian point $\mathrm{f}^{\mathrm{UT}}=\left(\mathrm{f}_{1 \mathrm{~min}}, \mathrm{f}_{2 \mathrm{~min}}, \ldots, \mathrm{f}_{\mathrm{mmin}}\right)$. The case $m=2$ (two objectives) is illustrated in Fig 2.

\subsection{Optimizing the multi-objective functions by the restricted area method (RAM)}

In fact, every objective function $f_{j}(Z)$ is restricted by the conditions set up by technology (Dzung N.T, et al., 2016a). Such as: a) Case 1: The obligatory conditions

$$
\mathrm{f}_{\mathrm{j}}(\mathrm{Z})<\mathrm{C}_{\mathrm{j}}, \forall \mathrm{j}=1 \div \mathrm{m}, \forall \mathrm{Z} \in \Omega_{\mathrm{Z}}
$$

From (6), the restricted area would be made:

$$
C=\left\{f_{j}(Z) \geq C_{j}\right\} \text {, with } f_{j}(Z)
$$

The restricted area method suggests the solution to the m-objective optimization problem $(1)+(2)+(3)$ by $R^{*}(\mathrm{Z})$ optimal combination criterion, defined as:

$$
\begin{aligned}
R^{*}(Z) & =\sqrt[m]{r_{1}(Z) \cdot r_{2}(Z) \ldots r_{m}(Z)} \\
& =\sqrt[m]{\prod_{j=1}^{m} r_{j}(Z)}
\end{aligned}
$$

With

$$
\begin{aligned}
& r_{j}(z)=\left(\frac{C_{j}-f_{j}(Z)}{C_{j}-f_{j \min }}\right) \text { when } f_{j}(z)<C_{j}(9) \\
& r_{j}(z)=0 \text { when } f_{j}(z) \geq C_{j}
\end{aligned}
$$

According to (9), if $\mathrm{f}_{\mathrm{j}}(\mathrm{Z}) \rightarrow \mathrm{f}_{\mathrm{j} \min }$ and $\forall \mathrm{f}_{\mathrm{j}}(\mathrm{Z})$ $<\mathrm{C}_{\mathrm{j}}, \mathrm{r}_{\mathrm{j}}(\mathrm{Z}) \rightarrow \mathrm{r}_{\mathrm{jmax}}=1$.

From (9), it can be seen: $0 \leq \mathrm{R}^{*}(\mathrm{ZR}) \leq 1$. If $\mathrm{R}^{*}(\mathrm{ZR})=1, \mathrm{ZR}=\mathrm{Z}^{\mathrm{UT}}-$ the utopian test. If $\mathrm{R} *(\mathrm{ZR})=0$, one of the values of $\mathrm{f}_{\mathrm{j}}(\mathrm{Z})$ violates (6), which means that $f_{j}(Z)$ belongs to the restricted area $\mathrm{C}(7)$.

b) Case 2: The obligatory conditions

$$
\begin{aligned}
& \mathrm{C}_{1 \mathrm{j}}<\mathrm{f}_{\mathrm{j}}(\mathrm{Z})<\mathrm{C}_{2 \mathrm{j}}, \\
& \forall \mathrm{j}=1 \div \mathrm{m}, \quad \forall \mathrm{Z} \in \Omega_{\mathrm{Z}}
\end{aligned}
$$

From (11), the restricted area would be made:

$$
\begin{aligned}
& C=\left\{f_{j}(Z) \geq C_{2 j} ;\right. \\
& \left.f_{j}(Z) \leq C_{1 j}\right\}, \text { with } f_{j}(Z) \in \Omega_{f}
\end{aligned}
$$

The restricted area method suggests the solution to the m-objective optimization problem $(1)+(2)+(3)$ by $R^{*}(Z)$ optimal combination criterion, defined as (8). 
With

$$
\begin{aligned}
& r_{j}(z)=\left(\frac{C_{2 j}-f_{j}(Z)}{C_{2 j}-f_{j \min }}\right)\left(\frac{f_{j \min }-C_{1 j}}{f_{j}(Z)-C_{1 j}}\right) \\
& \text { when } C_{1 j}<f_{j}(z)<C_{2 j} \\
& r_{j}(z)=0 \\
& \text { when } f_{j}(z) \geq C_{2 j} \text { or } f_{j}(z) \leq C_{1 j}
\end{aligned}
$$

According to (13), if $f_{j}(Z) \rightarrow f_{j}$ min and $\forall\left(\mathrm{C}_{1 \mathrm{j}}<\mathrm{f}_{\mathrm{j}}(\mathrm{Z})<\mathrm{C}_{2 \mathrm{j}}\right), \mathrm{r}_{\mathrm{j}}(\mathrm{Z}) \rightarrow \mathrm{r}_{\mathrm{jmax}}=1$.

By choosing $R^{*}(\mathrm{Z})$ as the objective function, the m-objective optimization problem is restated as:

Find $\mathrm{ZR}=\left(\mathrm{Z}_{1} \mathrm{R}, \mathrm{Z}_{2} \mathrm{R}, \ldots, \mathrm{Z}_{\mathrm{n}} \mathrm{R}\right) \in \Omega_{\mathrm{Z}}$ in order that $R^{*}(Z)$ reaches the maximum value.

$$
\begin{aligned}
& \mathrm{R}_{\text {max }}^{*}=\mathrm{R}^{*}(\mathrm{ZR})=\max \left\{\mathrm{R}^{*}(\mathrm{Z})\right\} \\
& \quad=\max \left\{\sqrt[m]{\left[\begin{array}{l}
\mathrm{m} \\
\prod_{j=1} \mathrm{r}_{\mathrm{j}}(\mathrm{Z})
\end{array}\right]}\right\} \\
& \forall \mathrm{Z}=\left(\mathrm{Z}_{1}, \ldots, \mathrm{Z}_{\mathrm{n}}\right) \in \Omega_{\mathrm{Z}}
\end{aligned}
$$

From (13), it can be seen: $0 \leq \mathrm{R}^{*}(\mathrm{ZR}) \leq 1$. If $\mathrm{R}^{*}(\mathrm{ZR})=1, \mathrm{ZR}=\mathrm{Z}^{\mathrm{UT}}-$ the utopian test. If $\mathrm{R}^{*}(\mathrm{ZR})=0$, one of the values of $\mathrm{f}_{\mathrm{j}}(\mathrm{Z})$ violates (11), which means that $f_{j}(Z)$ belongs to the restricted area $\mathrm{C}(12)$.

Theorem 3: If the multi-objective optimization problem (15) has its own ZR test, this ZR test is also the optimal Paréto test of the m-objective optimization problem (1) + (2) + (3), (Dzung N.T, et al., 2016a).

Symbol: $f(Z R)=f P R=\left(f_{1} P R, f_{2} P R, \ldots\right.$, $\left.f_{m} P R\right)$. With the optimal ZR, the optimal Paréto effect $\mathrm{fPR}=\left(\mathrm{f}_{1} \mathrm{PR}, \mathrm{f}_{2} \mathrm{PR}, \ldots, \mathrm{f}_{\mathrm{m}} \mathrm{PR}\right)$ would be the closest to the utopian point and the furthest from the restricted area $\mathrm{C}$.

\section{Materials and methods}

\subsection{Materials}

- The materials used for the cold drying experiments were mature Gac, mainly grown in Tay Nguyen area and Southeastern area of Vietnam (Anh Le, et al., 2018).
- Before the cold drying process, Gac was separated seeds and shells, the water content of Gac was $73.56 \%$.

\subsection{Apparatus}

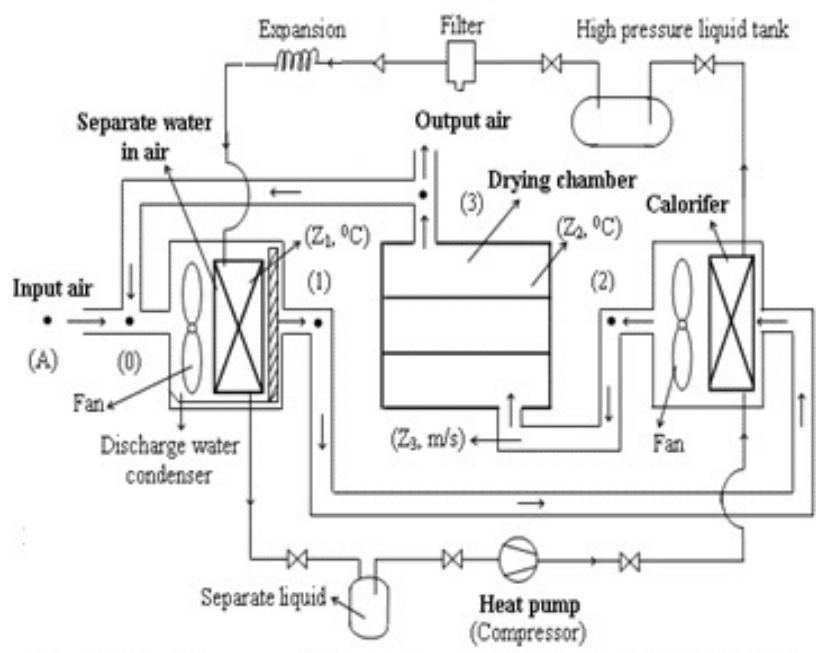

Figure 3. The diagram of cold drying DSL02 system.

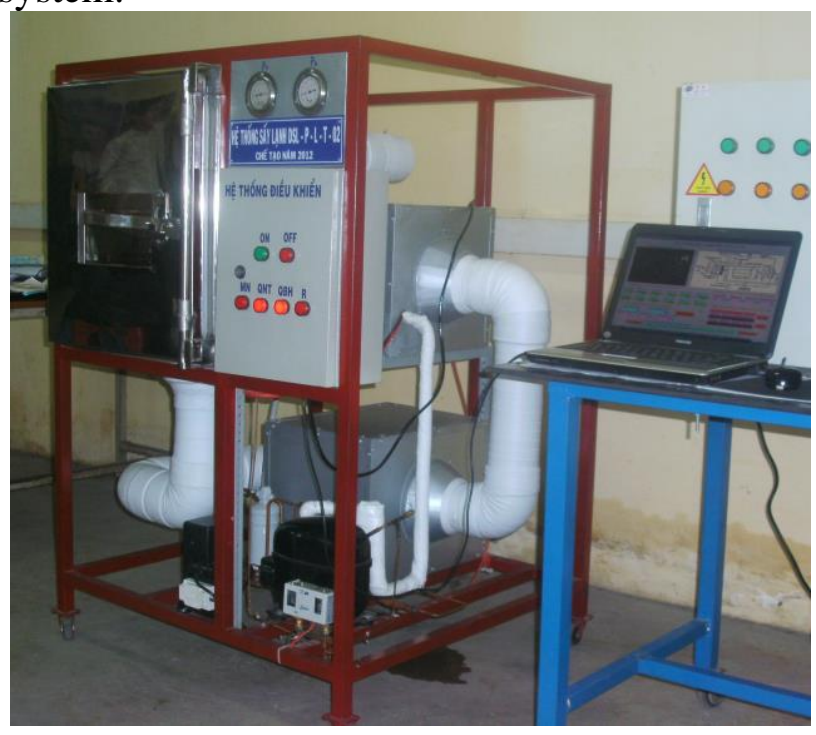

Figure 4. The cold drying DSL-02 system.

- The cold drying system DSL-02 controlled by PLC was used to dry Gac (Fig 3 and Fig 4), (Dzung N.T, et al., 2016a).

- Determining the weight of samples by Satoriusbasic Type BA310S and mass sensor with the range of 0 to $300 \mathrm{~g}$ and the error of $0.1 \mathrm{~g}$.

- Determining the volume of samples by Cylinders with the range of 0 to $500 \mathrm{ml}$ and the error of $0.1 \mathrm{~g}$. 
- Dual digital thermometer (T.P.34-23) and temperature sensor were used to determine the temperature of moisture condensation, the temperature of cold drying chamber during the cold drying process with the range of 0 to $100^{\circ} \mathrm{C}$ and the error of $0.5^{\circ} \mathrm{C}$.

- Determining time of the cold drying process by timer.

- Determining velocity drying agents by veloccity sensor (DMK-045) with the error of $0.01 \mathrm{~m} / \mathrm{s}$.

- The equipment of High Performance Liquid Chromatography (HPLC) was used to determine the content of $\beta$-carotene and lycopene in Gac.

\subsection{Methods}

- Determining the energy consumption ( $\mathrm{y}_{1}$, $\mathrm{kWh} / \mathrm{kg}$ product) for $1 \mathrm{~kg}$ finished product by Watt meter, (Dzung N.T, et al., 2016a).

$$
\mathrm{y}_{1}=\frac{\mathrm{U} \cdot \mathrm{I} \cdot \tau \cdot \cos \varphi}{\mathrm{G}}
$$

Where: $\quad \mathrm{G}(\mathrm{kg})$ - weight of finished product; $\mathrm{U}(\mathrm{V})$ - number of Voltmeter; I (A) - number of Amperemeter; $\tau$ (s) second; $\cos \varphi$ - power factor.

- Determining the residual water content of finished product $\left(\mathrm{y}_{2}, \%\right)$ by the mass sensor controlled by PLC, (Dzung N.T, et al., 2016a).

$$
\mathrm{y}_{2}=100-\frac{\mathrm{G}_{\mathrm{i}}}{\mathrm{G}_{\mathrm{e}}}\left(100-\mathrm{W}_{\mathrm{i}}\right)
$$

- Determining the anti-rehydration capacity of finished product $\left(\mathrm{y}_{3}, \%\right)$ indirectly by IR $(\%)$, which was the rehydration capacity of the finished product: $\mathrm{y}_{3}=100-\mathrm{IR}$, (Dzung N.T, et al., 2016a).

$$
\begin{aligned}
I R= & \frac{G_{1}-G_{e}}{G_{i}-G_{e}} \cdot 100 \% \\
& y_{3}=100-I R=\frac{G_{i}-G_{1}}{G_{i}-G_{e}} 100 \%
\end{aligned}
$$

Where: $\mathrm{G}_{\mathrm{i}}(\mathrm{kg})$ - weight of initial material used for cold drying; $G_{e}(\mathrm{~kg})$ - weight of finished product; $\mathrm{G}_{1}(\mathrm{~kg})$ - weight of finished product which was soaked into the water at $25^{\circ} \mathrm{C}$ until the constant mass (the saturation of water content); $\mathrm{W}_{\mathrm{i}}(\%)$ - initial water content of the material.

The ideal rehyration capacity of product means that the in-water content is equal to the out-water content of product, i.e. $\mathrm{G}_{1}=\mathrm{G}_{\mathrm{i}}$ and $\mathrm{IR}_{\max }=1=100 \%, \mathrm{y}_{3 \min }=0$. In fact, $\mathrm{y}_{3}>0, \mathrm{IR}$ $<100 \%$.

- Determining the loss of total $\beta$-carotene and lycopene in $\mathrm{Gac}$ of finished product $\left(\mathrm{y}_{4}, \%\right)$ by HPLC method in TCVN 4715 - 90.

$$
\mathrm{y}_{4}=\frac{\mathrm{m}_{1}-\mathrm{m}_{2}}{\mathrm{~m}_{1}} 100 \%=\frac{\Delta \mathrm{m}}{\mathrm{m}_{1}} 100 \%
$$

Where: $\quad y_{4}-$ the loss of total $\beta$-carotene and lycopene in Gac after cold drying; $\mathrm{m}_{1}$ and $\mathrm{m}_{2}(\mathrm{mg} \%)-$ the total $\beta$-carotene and lycopene in Gac before and after cold drying, respectively. The fact that the product achieves the best quality means $\mathrm{y}_{4 \mathrm{~min}}=0$. In fact, $\mathrm{y}_{4}>0$.

- Orthogonal experimental planning method with degree 2 (Dzung N.T, et al., 2016a).

- Establishing and solving 4-objective optimization problem by the restricted area method (Dzung N.T, et al., 2016a).

\section{Results and discussion}

\subsection{Establishing the constituent objective functions of the multi-objective problem}

The constituent objective functions of the cold drying process of Gac (including: the energy consumption per weight $\left(\mathrm{y}_{1}, \mathrm{kWh} / \mathrm{kg}\right)$; the residual water content $\left(\mathrm{y}_{2}, \%\right)$; the antirehydration capacity $\left(\mathrm{y}_{3}, \%\right)$ and the loss of total $\beta$-carotene and lycopene in $\mathrm{Gac}\left(\mathrm{y}_{4}, \%\right)$ of the cold-dried product) depended on the technological parameters, including: temperature of moisture condensation $\left(\mathrm{Z}_{1},{ }^{0} \mathrm{C}\right)$, temperature of cold drying chamber $\left(Z_{2},{ }^{0} \mathrm{C}\right)$, velocity drying agents $\left(Z_{3}, \mathrm{~m} / \mathrm{s}\right)$ and time of cold drying process $\left(Z_{4}, h\right)$. The objective functions $\mathrm{y}_{1}, \mathrm{y}_{2}, \mathrm{y}_{3}$ and $\mathrm{y}_{4}$ were described by the experimental planning method with the degree- 2 orthogonal experimental matrix. The experimental number was determined as:

$\mathrm{N}=\mathrm{n}_{\mathrm{k}}+\mathrm{n}^{*}+\mathrm{n}_{0}=2^{\mathrm{k}}+2 \mathrm{k}+\mathrm{n}_{0}=25$ 
Where: $\mathrm{k}=4 ; \mathrm{n}_{\mathrm{k}}=2^{\mathrm{k}}=2^{4}=16 ; \mathrm{n}^{*}=2 \mathrm{k}=2 \mathrm{x} 4$ $=8 ; \mathrm{n}_{0}=1$, carrying out 25 experiments.

These variables $\mathrm{x}_{1}, \mathrm{x}_{2}, \mathrm{x}_{3}, \mathrm{x}_{4}$ were coded variables of $\mathrm{Z}_{1}, \mathrm{Z}_{2}, \mathrm{Z}_{3}, \mathrm{Z}_{4}$ by the following expression:

$$
\mathrm{x}_{\mathrm{j}}=\left(\mathrm{Z}_{\mathrm{j}}-\mathrm{Z}_{\mathrm{j}}^{0}\right) / \Delta \mathrm{Z}_{\mathrm{j}}
$$

where: $\quad Z_{j}^{0}=\left(Z_{j}^{\max }+Z_{j}^{\min }\right) / 2$;

$$
\begin{aligned}
\Delta Z_{j}= & \left(Z_{j}^{\max }-Z_{j}^{\min }\right) / 2 ; \\
& Z_{j}^{\min } \leq Z_{j} \leq Z_{j}^{\max }
\end{aligned}
$$

The value of the star point:

$$
\alpha=\sqrt{\sqrt{\mathrm{N} .2^{(\mathrm{k}-2)}}-2^{(\mathrm{k}-1)}}=1.414
$$

And conditions of the orthogonal matrix:

$$
\lambda=\frac{1}{\mathrm{~N}}\left(2^{\mathrm{k}}+2 \alpha^{2}\right)=0.8
$$

Mathematical model of objective functions was defined by the following expression $[1,2$, 8, 10]:

$$
\begin{aligned}
y=b_{0} & +\sum_{j=1}^{k} b_{j} x_{j} \\
& +\sum_{j \neq i ; j=1}^{k} b_{j i} x_{j} x_{i}+\sum_{j=1}^{k} b_{j j} x_{j}^{2}
\end{aligned}
$$

The experimental conditions established the parameter levels affecting the cold drying process shown in table 1.

Table 1. Parameter level design

\begin{tabular}{|c|c|c|c|c|}
\hline Parameters & $\begin{array}{c}\mathrm{Z}_{1} \\
\left({ }^{0} \mathrm{C}\right)\end{array}$ & $\begin{array}{c}\mathrm{Z}_{2} \\
\left({ }^{0} \mathrm{C}\right)\end{array}$ & $\begin{array}{c}\mathrm{Z}_{3} \\
(\mathrm{~m} / \mathrm{s})\end{array}$ & $\begin{array}{c}\mathrm{Z}_{4} \\
(\mathrm{~h})\end{array}$ \\
\hline$-\alpha(-1.414)$ & 7.93 & 32.93 & 1.17 & 9.17 \\
\hline Low -1 & 10 & 35 & 2 & 10 \\
\hline Central 0 & 15 & 40 & 4 & 12 \\
\hline High +1 & 20 & 45 & 6 & 14 \\
\hline$+\alpha(1.414)$ & 22.07 & 47.07 & 6.83 & 14.83 \\
\hline Deviation $\Delta \mathrm{Z}_{\mathrm{i}}$ & 5 & 5 & 5 & 2 \\
\hline
\end{tabular}

\subsubsection{Establishing the mathematical model of objective functions $y_{1}, y_{2}, y_{3}$ and $y_{4}$}

The experiments were carried out with all of the parameter levels in table 1 to determine the value of the objective functions. The result was summarized in table 2 .

Table 2. The degree-2 orthogonal experimental matrix, $\mathrm{k}=4, \mathrm{n}_{0}=4, \mathrm{n}=28, \alpha=1.414, \lambda=0.8$

\begin{tabular}{|c|c|c|c|c|c|c|c|c|c|c|c|c|c|c|c|c|c|c|c|c|}
\hline \multicolumn{2}{|c|}{} & $\mathrm{x}_{0}$ & $\mathrm{x}_{1}$ & $\mathrm{x}_{2}$ & $\mathrm{x}_{3}$ & $\mathrm{x}_{4}$ & $\mathrm{x}_{1} \mathrm{x}_{2}$ & $\mathrm{x}_{1} \mathrm{x}_{3}$ & $\mathrm{x}_{1} \mathrm{x}_{4}$ & $\mathrm{x}_{2} \mathrm{x}_{3}$ & $\mathrm{x}_{2} \mathrm{x}_{4}$ & $\mathrm{x}_{3} \mathrm{x}_{4}$ & $\mathrm{x}_{1}{ }^{2}-\lambda$ & $\mathrm{x}_{2}{ }^{2}-\lambda$ & $\mathrm{x}_{3}{ }^{2}-\lambda$ & $\mathrm{x}_{4}{ }^{2}-\lambda$ & $\mathrm{y}_{1}$ & $\mathrm{y}_{2}$ & $\mathrm{y}_{3}$ & $\mathrm{y}_{4}$ \\
\hline 1 & 1 & -1 & -1 & -1 & -1 & 1 & 1 & 1 & 1 & 1 & 1 & 0.2 & 0.2 & 0.2 & 0.2 & 1.21 & 11.34 & 12.76 & 4.32 \\
\hline 2 & 1 & 1 & -1 & -1 & -1 & -1 & -1 & -1 & 1 & 1 & 1 & 0.2 & 0.2 & 0.2 & 0.2 & 1.31 & 10.34 & 11.63 & 4.65 \\
\hline 3 & 1 & -1 & 1 & -1 & -1 & -1 & 1 & 1 & -1 & -1 & 1 & 0.2 & 0.2 & 0.2 & 0.2 & 1.46 & 9.34 & 10.51 & 5.6 \\
\hline 4 & 1 & 1 & 1 & -1 & -1 & 1 & -1 & -1 & -1 & -1 & 1 & 0.2 & 0.2 & 0.2 & 0.2 & 1.32 & 8.73 & 9.82 & 5.24 \\
\hline 5 & 1 & -1 & -1 & 1 & -1 & 1 & -1 & 1 & -1 & 1 & -1 & 0.2 & 0.2 & 0.2 & 0.2 & 1.31 & 9.24 & 10.4 & 5.54 \\
\hline 6 & 1 & 1 & -1 & 1 & -1 & -1 & 1 & -1 & -1 & 1 & -1 & 0.2 & 0.2 & 0.2 & 0.2 & 1.53 & 8.56 & 9.63 & 5.14 \\
\hline 7 & 1 & -1 & 1 & 1 & -1 & -1 & -1 & 1 & 1 & -1 & -1 & 0.2 & 0.2 & 0.2 & 0.2 & 1.40 & 9.13 & 10.27 & 5.48 \\
\hline $2^{\mathrm{k}}$ & \begin{tabular}{c}
$\mathrm{k}$ \\
\hline 8
\end{tabular} & 1 & 1 & -1 & 1 & 1 & -1 & 1 & -1 & 1 & -1 & 0.2 & 0.2 & 0.2 & 0.2 & 1.71 & 9.83 & 11.06 & 5.9 \\
\hline 9 & 1 & -1 & -1 & -1 & 1 & 1 & 1 & -1 & 1 & -1 & -1 & 0.2 & 0.2 & 0.2 & 0.2 & 1.83 & 7.25 & 8.16 & 4.35 \\
\hline 10 & 1 & 1 & -1 & -1 & 1 & -1 & -1 & 1 & 1 & -1 & -1 & 0.2 & 0.2 & 0.2 & 0.2 & 1.92 & 8.04 & 9.05 & 4.82 \\
\hline 11 & 1 & -1 & 1 & -1 & 1 & -1 & 1 & -1 & -1 & 1 & -1 & 0.2 & 0.2 & 0.2 & 0.2 & 1.83 & 8.34 & 9.38 & 5.01 \\
\hline 12 & 1 & 1 & 1 & -1 & 1 & 1 & -1 & 1 & -1 & 1 & -1 & 0.2 & 0.2 & 0.2 & 0.2 & 2.09 & 6.34 & 7.13 & 4.81 \\
\hline 13 & 1 & -1 & -1 & 1 & 1 & 1 & -1 & -1 & -1 & -1 & 1 & 0.2 & 0.2 & 0.2 & 0.2 & 1.77 & 6.46 & 7.27 & 4.88 \\
\hline 14 & 1 & 1 & -1 & 1 & 1 & -1 & 1 & 1 & -1 & -1 & 1 & 0.2 & 0.2 & 0.2 & 0.2 & 1.87 & 7.46 & 8.39 & 4.48 \\
\hline 15 & 1 & -1 & 1 & 1 & 1 & -1 & -1 & -1 & 1 & 1 & 1 & 0.2 & 0.2 & 0.2 & 0.2 & 2.09 & 7.73 & 8.7 & 4.64 \\
\hline 16 & 1 & 1 & 1 & 1 & 1 & 1 & 1 & 1 & 1 & 1 & 1 & 0.2 & 0.2 & 0.2 & 0.2 & 2.14 & 5.89 & 7.43 & 6.23 \\
\hline
\end{tabular}




\begin{tabular}{|l|c|c|c|c|c|c|c|c|c|c|c|c|c|c|c|c|c|c|c|c|}
\hline & 17 & 1 & 1.414 & 0 & 0 & 0 & 0 & 0 & 0 & 0 & 0 & 0 & 1.2 & -0.8 & -0.8 & -0.8 & 1.43 & 7.46 & 8.39 & 4.48 \\
\hline 18 & 1 & -1.414 & 0 & 0 & 0 & 0 & 0 & 0 & 0 & 0 & 0 & 1.2 & -0.8 & -0.8 & -0.8 & 1.25 & 7.05 & 7.93 & 4.26 \\
\hline 19 & 1 & 0 & 1.414 & 0 & 0 & 0 & 0 & 0 & 0 & 0 & 0 & -0.8 & 1.2 & -0.8 & -0.8 & 1.35 & 8.45 & 9.51 & 5.07 \\
\hline \multirow{4}{*}{$2 \mathrm{k}$} & 1 & 0 & -1.414 & 0 & 0 & 0 & 0 & 0 & 0 & 0 & 0 & -0.8 & 1.2 & -0.8 & -0.8 & 1.31 & 8.31 & 9.35 & 4.99 \\
\hline & 21 & 1 & 0 & 0 & 1.414 & 0 & 0 & 0 & 0 & 0 & 0 & 0 & -0.8 & -0.8 & 1.2 & -0.8 & 1.84 & 7.56 & 8.51 & 4.54 \\
\hline 22 & 1 & 0 & 0 & -1.414 & 0 & 0 & 0 & 0 & 0 & 0 & 0 & -0.8 & -0.8 & 1.2 & -0.8 & 1.41 & 8.56 & 9.63 & 5.14 \\
\hline & 23 & 1 & 0 & 0 & 0 & 1.414 & 0 & 0 & 0 & 0 & 0 & 0 & -0.8 & -0.8 & -0.8 & 1.2 & 2.25 & 6.34 & 7.13 & 6.81 \\
\hline & 24 & 1 & 0 & 0 & 0 & -1.414 & 0 & 0 & 0 & 0 & 0 & 0 & -0.8 & -0.8 & -0.8 & 1.2 & 1.61 & 8.02 & 9.02 & 4.81 \\
\hline $\mathrm{n}_{0}$ & 25 & 1 & 0 & 0 & 0 & 0 & 0 & 0 & 0 & 0 & 0 & 0 & -0.8 & -0.8 & -0.8 & -0.8 & 1.53 & 7.55 & 8.49 & 4.53 \\
\hline
\end{tabular}

The regression equations (24), (25), (26) and (27) were obtained after processing the experimental data, calculating the coefficients, testing the significance of the coefficients by the Student test, and testing the regression equations for the fitness of the experimental results by Fisher test [8]:

$$
\begin{aligned}
& \mathrm{y}_{1}=1.462+0.062 \mathrm{x}_{1}+0.067 \mathrm{x}_{2}-0.098 \mathrm{x}_{3} \\
& +0.43 \mathrm{x}_{4}-0.19 \mathrm{x}_{1} \mathrm{x}_{3}+0.214 \mathrm{x}_{1} \mathrm{x}_{2} \\
& -0.187 \mathrm{x}_{2} \mathrm{x}_{3}+0.227 \mathrm{x}_{2} \mathrm{x}_{4}-0.028 \mathrm{x}_{3} \mathrm{x}_{4} \\
& \quad-0.059\left(\mathrm{x}_{1}^{2}-0.8\right)-0.062\left(\mathrm{x}_{2}^{2}-0.8\right) \\
& +0.083\left(\mathrm{x}_{1}^{2}-0.8\right)+0.237\left(\mathrm{x}_{2}^{2}-0.8\right) \\
& \mathrm{y}_{2}=8.133-1.325 \mathrm{x}_{3}-1.104 \mathrm{x}_{1} \mathrm{x}_{3}+1.2 \mathrm{x}_{1} \mathrm{x}_{4} \\
& +0.91 \mathrm{x}_{2} \mathrm{x}_{3}-1.325 \mathrm{x}_{2} \mathrm{x}_{4} \\
& \quad+0.048\left(\mathrm{x}_{2}{ }^{2}-0.8\right) \\
& \mathrm{y}_{3}=9.15-1.49 \mathrm{x}_{3}-0.27 \mathrm{x}_{1} \mathrm{x}_{2} \\
& \quad 1.242 \mathrm{x}_{1} \mathrm{x}_{3}+1.35 \mathrm{x}_{1} \mathrm{x}_{4}-1.024 \mathrm{x}_{2} \mathrm{x}_{3} \\
& \quad+1.491 \mathrm{x}_{2} \mathrm{x}_{4}+0.689\left(\mathrm{x}_{2}{ }^{2}-0.8\right) \\
& \mathrm{y}_{4}=4.978+0.106 \mathrm{x}_{1}+0.3 \mathrm{x}_{2}-0.396 \mathrm{x}_{3} \\
& +0.66 \mathrm{x}_{4}-0.7 \mathrm{x}_{1} \mathrm{x}_{3}+0.81 \mathrm{x}_{1} \mathrm{x}_{4} \\
& -0.83 \mathrm{x}_{2} \mathrm{x}_{3}+0.634 \mathrm{x}_{2} \mathrm{x}_{4}-0.14 \mathrm{x}_{3} \mathrm{x}_{4} \\
& \quad 0.29\left(\mathrm{x}_{1}{ }^{2}-0.8\right)+0.44\left(\mathrm{x}_{4}{ }^{2}-0.8\right)(27)
\end{aligned}
$$

\subsubsection{Establishing the mathematical model of multi-objective functions}

The technological parameters $\left(\mathrm{x}_{1}, \mathrm{x}_{2}, \mathrm{x}_{3}\right.$ and $\mathrm{X}_{4}$ ) of the cold drying process of Gac had the simultaneous impact on these objective functions $\left(\mathrm{y}_{1}, \mathrm{y}_{2}, \mathrm{y}_{3}\right.$ and $\left.\mathrm{y}_{4}\right)$ with the identified domain $\Omega_{\mathrm{x}}=\left\{-1.414 \leq \mathrm{x}_{1}, \mathrm{x}_{2}, \mathrm{x}_{3}, \mathrm{x}_{4} \leq 1.414\right\}$. Thus, the four-objective optimization problem determining the technological cold drying mode of Gac was restated as: Finding in common the test $\mathrm{x}=\left(\mathrm{x}_{1}{ }^{\text {opt }}, \mathrm{x}_{2}{ }^{\text {opt }}, \mathrm{x}_{3}{ }^{\text {opt }}, \mathrm{x}_{4}{ }^{\text {opt }}\right) \in$ $\Omega_{\mathrm{x}}=\left\{-1.414 \leq \mathrm{x}_{1}, \mathrm{x}_{2}, \mathrm{x}_{3}, \mathrm{x}_{4} \leq 1.414\right\}$ in order that:

$$
\begin{aligned}
& \mathrm{y}_{1}=\mathrm{f}_{1 \min }\left(\mathrm{x}_{1}{ }^{\mathrm{opt}}, \mathrm{x}_{2}{ }^{\mathrm{opt}}, \mathrm{x}_{3}{ }^{\mathrm{opt}}, \mathrm{x}_{4}{ }^{\mathrm{opt}}\right)=\min \mathrm{f}_{1}\left(\mathrm{x}_{1}, \mathrm{x}_{2}, \mathrm{x}_{3}, \mathrm{x}_{4}\right) \\
& \mathrm{y}_{2}=\mathrm{f}_{2 \min }\left(\mathrm{x}_{1}{ }^{\mathrm{opt}}, \mathrm{x}_{2}{ }^{\mathrm{opt}}, \mathrm{x}_{3}{ }^{\mathrm{opt}}, \mathrm{x}_{4}{ }^{\text {opt }}\right)=\min \mathrm{f}_{1}\left(\mathrm{x}_{1}, \mathrm{x}_{2}, \mathrm{x}_{3}, \mathrm{x}_{4}\right) \\
& \mathrm{y}_{3}=\mathrm{f}_{3 \min }\left(\mathrm{x}_{1}{ }^{\mathrm{opt}}, \mathrm{x}_{2}{ }^{\text {opt }}, \mathrm{x}_{3}{ }^{\mathrm{opt}}, \mathrm{x}_{4}{ }^{\text {opt }}\right)=\min \mathrm{f}_{1}\left(\mathrm{x}_{1}, \mathrm{x}_{2}, \mathrm{x}_{3}, \mathrm{x}_{4}\right) \\
& \mathrm{y}_{4}=\mathrm{f}_{4 \min }\left(\mathrm{x}_{1}{ }^{\text {opt }}, \mathrm{x}_{2}{ }^{\text {opt }}, \mathrm{x}_{3}{ }^{\text {opt }}, \mathrm{x}_{4}{ }^{\text {opt }}\right)=\min \mathrm{f}_{1}\left(\mathrm{x}_{1}, \mathrm{x}_{2}, \mathrm{x}_{3}, \mathrm{x}_{4}\right) \\
& \forall \mathrm{x}=\left(\mathrm{x}_{1}, \mathrm{x}_{2}, \mathrm{x}_{3}, \mathrm{x}_{4}\right) \in \Omega_{\mathrm{X}}
\end{aligned}
$$

Where: $\quad \mathrm{y}_{1}<\mathrm{C}_{1}=2.5$;

$$
\begin{aligned}
& \mathrm{C}_{21}=5.2<\mathrm{y}_{2}<8.5=\mathrm{C}_{22} ; \\
& \mathrm{y}_{3}<\mathrm{C}_{3}=10.5 ; \\
& \mathrm{y}_{4}<\mathrm{C}_{4}=4.5
\end{aligned}
$$

The establishment of the cold drying mode of $\mathrm{Gac}$ was based on factors including: economic, technicality and quality of the product obtained. Experimental results were obvious that: if the energy consumption for the production of $1 \mathrm{~kg}$ product was higher than $2.5 \mathrm{kWh}$, it would increase the product price and difficult commercialization. If the antirehydration capacity of the final product was greater than $10.5 \%$, Gac would be denatured, not able to recover the original of its quality. As a result, quality of product was reduced. If the loss of total $\beta$-carotene and lycopene in $\mathrm{Gac}$ of the final product was greater than $5.5 \%$, natural color and flavor of Gac would be destroyed and nutritional value of product reduced. In addition, if the residual water content of the final product was greater than $8.5 \%$, the microorganisms would be capable to grow, develop and damage products. On the other hand, if residual water content of final 
product was less than $5.2 \%$, the final product would be completely denatured. According to $[6,10]$, if the multi-objective optimization problem was solved by the utopian point method, value of the objective functions $\left(\mathrm{y}_{1}, \mathrm{y}_{2}\right.$, $\mathrm{y}_{3}$ and $\mathrm{y}_{4}$ ) would not satisfy conditions (29) so the multi-objective optimization problem have to be solved by the restricted area method.

\subsection{Solving the one-objective optimization problems}

These one-objective optimization problems were found to achieve: $\mathrm{y}_{1 \text { min }}=\operatorname{miny}_{1}\left(\mathrm{x}_{1}, \mathrm{x}_{2}, \mathrm{x}_{3}\right.$, $\left.\mathrm{x}_{4}\right) ; \mathrm{y}_{2} \min =\operatorname{miny}_{2}\left(\mathrm{x}_{1}, \mathrm{x}_{2}, \mathrm{x}_{3}, \mathrm{x}_{4}\right) ; \mathrm{y}_{3} \min =$ $\operatorname{miny}_{3}\left(\mathrm{x}_{1}, \mathrm{x}_{2}, \mathrm{x}_{3}, \mathrm{x}_{4}\right) ; \mathrm{y}_{4} \min =\operatorname{miny}_{4}\left(\mathrm{x}_{1}, \mathrm{x}_{2}, \mathrm{x}_{3}\right.$, $\left.\mathrm{x}_{4}\right)$, with the identified domain $\Omega_{\mathrm{x}}=\{-1.414 \leq$ $\left.\mathrm{x}_{1}, \mathrm{x}_{2}, \mathrm{x}_{3}, \mathrm{x}_{4} \leq 1.414\right\}$. By the meshing method programmed in Matlab 7.0, the results of optimal parameters of every objective function (24), (25), (26) and (27) limited in the experimental domain were summarized in table 3.

Table 3. Minimum tests of each oneobjective optimization problem (Material drying of Gac)

\begin{tabular}{|c|c|c|c|c|c|}
\hline $\mathbf{j}$ & $\mathbf{y j m i n}^{\mathbf{j}}$ & $\mathbf{x 1}^{\mathbf{j} \text { opt }}$ & $\mathbf{x 2}^{\mathbf{j} \text { opt }}$ & $\mathbf{x 3}^{\mathbf{j} \text { opt }}$ & $\mathbf{x 4}^{\mathbf{j} \text { opt }}$ \\
\hline 1 & 1.21 & -1.000 & -1.000 & -1.000 & -1.000 \\
\hline 2 & 5.31 & -1.414 & 1.414 & 1.414 & 1.414 \\
\hline 3 & 7.03 & -0.563 & -0.987 & 0.856 & 1.023 \\
\hline 4 & 4.13 & -0.978 & 0.753 & 0.974 & -0.907 \\
\hline
\end{tabular}

According to the table 3, the utopian points were indentified: $\mathrm{y}^{\mathrm{UT}}=\left(\mathrm{y}_{1} \min , \mathrm{y}_{2} \mathrm{~min}, \mathrm{y}_{3} \min , \mathrm{y}_{4 \mathrm{~min}}\right)$ $=(1.21,5.31,7.03,4.21)$. However, the utopian plan did not exist, because of $\mathrm{x}^{\text {jopt }}=\left(\mathrm{x}_{1}{ }^{\text {jopt }}\right.$, $\left.\mathrm{x}_{2}{ }^{\text {jopt }}, \mathrm{x}_{3}{ }^{\text {jopt }}, \mathrm{x}_{4}{ }^{\text {jopt }}\right) \neq \mathrm{x}^{\text {kopt }}=\left(\mathrm{x}_{1}{ }^{\text {kopt }}, \mathrm{x}_{2}{ }^{\text {kopt }}, \mathrm{x}_{3}{ }^{\text {kopt }}\right.$, $\mathrm{x}_{4}{ }^{\text {kopt}}$ ) where $\mathrm{j}, \mathrm{k}=1$ to 4 , and $\mathrm{j} \neq \mathrm{k}$.

\subsection{Solving the multi-objective optimization problem by the restricted area method}

The purpose of the experiment was to reach the target of cold drying process of Gac which was expressed by 4 regression equations (24), (25), (26) and (27) but the test satisfying all function values $\left(\mathrm{y}_{1} \mathrm{~min}, \mathrm{y}_{2} \mathrm{~min}, \mathrm{y}_{3} \mathrm{~min}, \mathrm{y}_{4 \mathrm{~min}}\right)$ could not be found. Hence, the idea of the four- objective optimization problem was to find the optimal Pareto test for the optimal Pareto effect $\mathrm{y}(\mathrm{xR})=\mathrm{yPR}=\left(\mathrm{y}_{1} \mathrm{PR}, \mathrm{y}_{2} \mathrm{PR}, \mathrm{y}_{3} \mathrm{PR}, \mathrm{y}_{4} \mathrm{PR}\right)$ closest to the utopian point $\mathrm{y}^{\mathrm{UT}}=\left(\mathrm{y}_{1} \mathrm{~min}, \mathrm{y}_{2} \mathrm{~min}\right.$, $\left.\mathrm{y}_{3 \min }, \mathrm{y}_{4 \mathrm{~min}}\right)=(1.21,5.31,7.03,4.21)$.

Establishing the $\mathrm{R} *$-objective combination function $\mathrm{R}^{*}\left(\mathrm{y}_{1}, \mathrm{y}_{2}, \mathrm{y}_{3}, \mathrm{y}_{4}\right)=\mathrm{R}^{*}\left(\mathrm{x}_{1}, \mathrm{x}_{2}, \mathrm{x}_{3}, \mathrm{x}_{4}\right)=$ $\mathrm{R}^{*}(\mathrm{x})$ as the followings:

$$
\left\{\begin{array}{l}
\mathrm{R}^{*}(\mathrm{x})=\sqrt[4]{\mathrm{r}_{1}(\mathrm{x}) \cdot \mathrm{r}_{2}(\mathrm{x}) \cdot \mathrm{r}_{3}(\mathrm{x}) \cdot \mathrm{r}_{4}(\mathrm{x})}=\sqrt[4]{\prod_{j=1} \mathrm{r}_{j}(\mathrm{x})} \\
\Omega_{\mathrm{x}}=\left\{-1.414 \leq \mathrm{x}_{1}, \mathrm{x}_{2}, \mathrm{x}_{3}, \mathrm{x}_{4} \leq 1.414\right\}
\end{array}\right.
$$

Where: with conditions (29), thus $\mathrm{r}_{1}(\mathrm{x})$, $r_{2}(x), r_{3}(x)$ and $r_{4}(x)$ can be established as (9) and (13):

$$
\begin{aligned}
& \mathrm{r}_{1}(\mathrm{x})=\left(2.5-\mathrm{y}_{1}\right) /\left(2.5-\mathrm{y}_{1 \mathrm{~min}}\right) \\
& \text { when } \mathrm{y}_{1}<2.5 ; \\
& \mathrm{r}_{1}(\mathrm{x})=0 \quad \text { when } \mathrm{y}_{1} \geq 2.5 \\
& \mathrm{r}_{2}(\mathrm{x})=\left[\left(8.5-\mathrm{y}_{2}\right) /\left(8.5-\mathrm{y}_{2 \mathrm{~min}}\right)\right]\left[\left(\mathrm{y}_{2 \mathrm{~min}}-5.2\right) /\left(\mathrm{y}_{2}-\right.\right. \\
& 5.2)] \quad \text { when } 5.2<\mathrm{y}_{2}<8.5 \\
& \mathrm{r}_{2}(\mathrm{x})=0 \quad \text { when } \mathrm{y}_{2} \leq 5.2 \text { or } \mathrm{y}_{2} \geq 8.5 \\
& \mathrm{r}_{3}(\mathrm{x})=\left(10.5-\mathrm{y}_{3}\right) /\left(10.5-\mathrm{y}_{3 \mathrm{~min}}\right) \\
& \text { when } \mathrm{y}_{3}<10.5 \\
& \mathrm{r}_{3}(\mathrm{x})=0 \quad \text { when } \mathrm{y}_{3} \geq 10.5 \\
& \mathrm{r}_{4}(\mathrm{x})=\left(5.5-\mathrm{y}_{4}\right) /\left(5.5-\mathrm{y}_{4} \min \right) \\
& \text { when } \mathrm{y}_{4}<5.5 \\
& \mathrm{r}_{4}(\mathrm{x})=0 \quad \text { when } \mathrm{y}_{4} \geq 5.5
\end{aligned}
$$

With: $y_{1} \min , y_{2 m i n}, y_{3 m i n}, y_{4 m i n}$ were showed in Table 3

The four-objective optimization problem needed to indentify $x R=\left(x_{1} R, x_{2} R, x_{3} R, x_{4} R\right)$ $\in \Omega_{\mathrm{x}}$ in order that $\mathrm{R}^{*}\left(\mathrm{x}_{1} \mathrm{R}, \mathrm{x}_{2} \mathrm{R}, \mathrm{x}_{3} \mathrm{R}, \mathrm{x}_{4} \mathrm{R}\right)=$ $\operatorname{Max}\left\{\mathrm{R}^{*}\left(\mathrm{x}_{1}, \mathrm{x}_{2}, \mathrm{x}_{3}, \mathrm{x}_{4}\right)\right\}$. The maximum value of (30) was determined by the meshing method programmed in Matlab 7.0:

$$
\begin{array}{ll}
\mathrm{R}^{*}{ }_{\max }=\operatorname{Max}\left\{\mathrm{R} *\left(\mathrm{x}_{1}, \mathrm{x}_{2}, \mathrm{x}_{3}, \mathrm{x}_{4}\right)\right\}=0.671 \\
\text { With: } \quad \mathrm{x}_{1} \mathrm{R}=-1.034 ; \\
\mathrm{x}_{2} \mathrm{R}=0.835 ; \\
\mathrm{x}_{3} \mathrm{R}=-0.271 ; \\
\mathrm{x}_{4} \mathrm{R}=0.182 ;
\end{array}
$$

Then, transforming into real variables:

$$
\begin{aligned}
& \mathrm{Z}_{1}{ }^{\mathrm{opt}}=9.83^{0} \mathrm{C} ; \\
& \mathrm{Z}_{2}{ }^{\mathrm{opt}}=44.18{ }^{0} \mathrm{C} ; \\
& \mathrm{Z}_{3}{ }^{\mathrm{opt}}=3.46 \mathrm{~m} / \mathrm{s} ; \\
& \mathrm{Z}_{4}{ }^{\mathrm{opt}}=12.36 \mathrm{~h} ;
\end{aligned}
$$


Substituting $\mathrm{x}_{1} \mathrm{R}, \mathrm{x}_{2} \mathrm{R}, \mathrm{x}_{3} \mathrm{R}, \mathrm{x}_{4} \mathrm{R}$ into these equations (24), (25), (26) and (27), the optimal Pareto effect was obtained as: $\mathrm{y}_{1} \mathrm{PR}=2.09$; $\mathrm{y}_{2} \mathrm{PR}=7.86 ; \mathrm{y}_{3} \mathrm{PR}=8.997 ; \mathrm{y}_{4} \mathrm{PR}=5.07 ;$

The rehydration capacity of the cold-dried product was determined as:

$\mathrm{IR}=100-\mathrm{y}_{3} \mathrm{PR}=100-8.997=91.003 \%$

By the restricted area method, solving the multi-objective optimization problem with $\mathrm{R}^{*}$ Optimal combination criterion which satisfied the maximum $\mathrm{R}^{*}$-Optimal combination criterion $\left(\mathrm{R}^{*}{ }_{\min }=0.671\right)$ was determined the optimal Pareto test (or the technological mode of cold drying process of $\mathrm{Gac}$ ) as: temperature of moisture condensation was $\mathrm{Z}_{1}{ }^{\text {opt }}=9.83^{\circ} \mathrm{C}$, temperature of cold drying chamber was $\mathrm{Z}_{2}{ }^{\mathrm{opt}}=$ $44.18^{\circ} \mathrm{C}$, the velocity drying agents was $\mathrm{Z}_{3}{ }^{\text {opt }}=$ $3.46 \mathrm{~m} / \mathrm{s}$ and the time of cold drying process was $\mathrm{Z}_{4}{ }^{\text {opt }}=12.36 \mathrm{~h}$. Corresponding with the optimal Pareto test was determined the optimal Pareto effect as: the energy consumption per weight of $1 \mathrm{~kg}$ finished product was $\mathrm{y}_{1} \mathrm{PR}=$ $2.09 \mathrm{kWh} / \mathrm{kg}$; the residual water content of the finished product was $\mathrm{y}_{2} \mathrm{PR}=7.86 \%$; the antirehydration capacity of the finished product was $\mathrm{y}_{3} \mathrm{PR}=8.997 \%$ (Correspondingly $\mathrm{IR}=$ $91.003 \%)$ and the loss of total $\beta$-carotene and lycopene in $\mathrm{Gac}$ of the finished product was $\mathrm{y}_{4} \mathrm{PR}=5.07 \%$.

Compared with the experimental results from the table 3 , these results above were suitable and satisfy with the objectives of the problem.

\subsection{Experiment to test the results of multi- objective optimization problem}

Carrying out the cold drying process of Gac at the optimal Pareto test: temperature of moisture condensation of $\mathrm{Z}_{1}^{\mathrm{opt}}=9.83^{\circ} \mathrm{C}$, temperature of cold drying chamber of $\mathrm{Z}_{2}{ }^{\mathrm{opt}}=$ $34.18^{\circ} \mathrm{C}$, the velocity drying agents of $\mathrm{Z}_{3}{ }^{\mathrm{opt}}=$ $3.46 \mathrm{~m} / \mathrm{s}$, and the time of cold drying process of $\mathrm{Z}_{4}{ }^{\text {opt }}=12.36$ hours, the experimental results were determined as: The energy consumption per weight of $\mathrm{y}_{1}=2.16 \mathrm{kWh} / \mathrm{kg}$; the residual water content of $\mathrm{y}_{2}=7.45 \%$; the antirehydration capacity of $\mathrm{y}_{3}=8.69 \%$ (or the rehydration capacity of $\mathrm{IR}=100-\mathrm{y}_{3}=$
$91.31 \%)$ and the loss of total $\beta$-carotene and lycopene in Gac of $\mathrm{y}_{4}=5.04 \%$ of the colddried product. Consequently, it was very noticeable that the results from the optimization problems of cold drying process of Gac had the approximation to the experimental results.

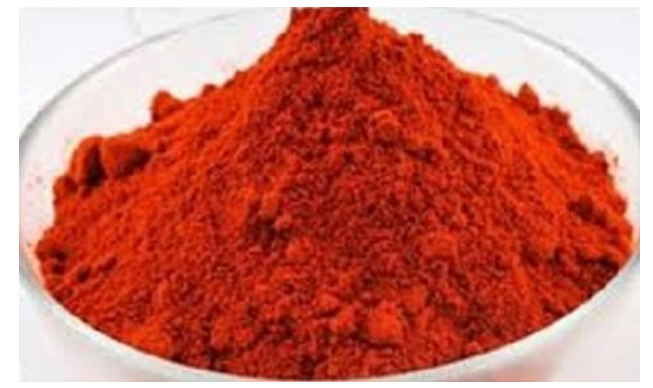

Figure 5. Gac was dried by the cold drying method

After Gac was dried by the cold drying method at the optimal Pareto test: $\mathrm{Z}_{1}{ }^{\mathrm{opt}}=$ $9.83^{0} \mathrm{C} ; \mathrm{Z}_{2}{ }^{\text {opt }}=44.18^{0} \mathrm{C} ; \mathrm{Z}_{3}{ }^{\text {opt }}=3.46 \mathrm{~m} / \mathrm{s} ; \mathrm{Z}_{4}{ }^{\text {opt }}=$ 12.36h. The finished product obtained could be seen in Fig 5.

It was certain that the optimal Pareto test and the optimal Pareto effect of the multiobjective optimization problem of cold drying process of Gac could be possibly applied to determine the technological mode of cold drying process of Gac for using in the industry.

When the velocity air or drying agents and the time of cold drying process were fixed: $\mathrm{x}_{3}=$ -0.271 and $\mathrm{x}_{4}=0.182$, correspondingly $\mathrm{Z}_{3}=$ $3.46 \mathrm{~m} / \mathrm{s}$ and $\mathrm{Z}_{4}=12.36 \mathrm{~h}$, the relationship between $\mathrm{y}_{1}, \mathrm{y}_{2}, \mathrm{IR}=100-\mathrm{y}_{3}$, and $\mathrm{y}_{4}$ with 2 variables $\mathrm{x}_{1}, \mathrm{x}_{2}$ was performed geometrically in 3D (Fig 6, 7, 8, 9).

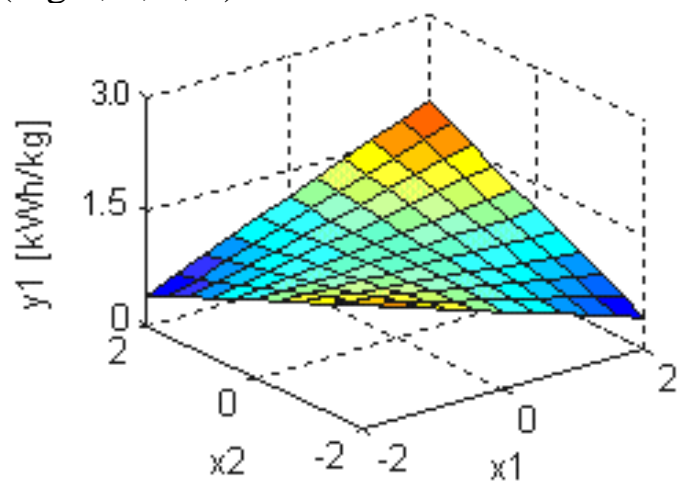

Fig 6. The energy consumption, $x 3=-0,271$ and $\times 4=0.182$ 


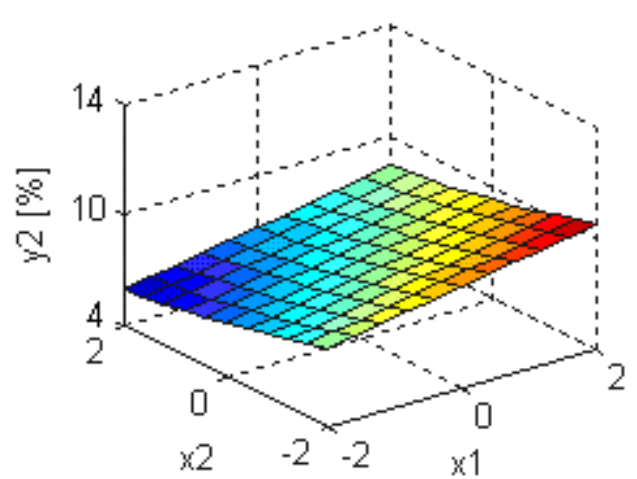

Fig 7 . The residual water content of product, $\times 3=-0.271$ and $\times 4=0.182$

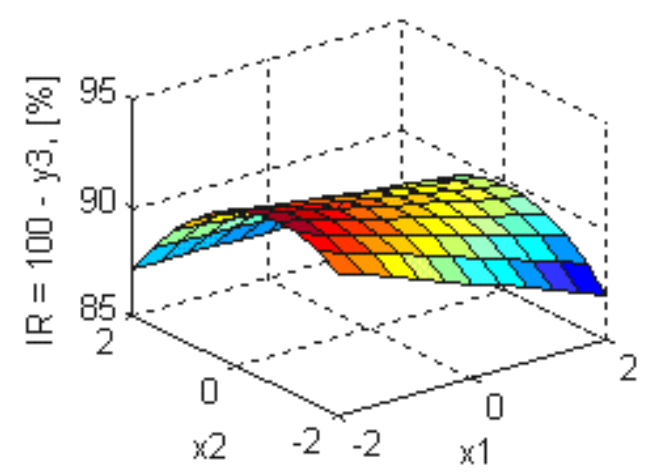

Fig 8 . The rehydration capacity of product, $\times 3=-0.271$ and $\times 4=0.182$

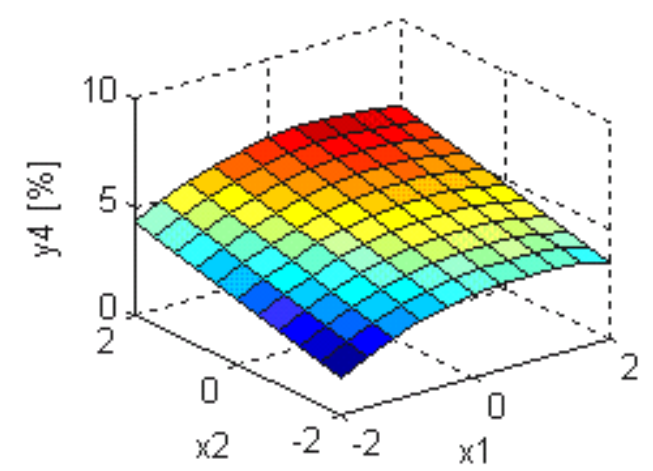

Fig 9. The loss of total $\beta$-carotene and lycopene of product, $\mathrm{x} 3=-0.271$ and $\mathrm{x} 4=0.182$

\section{Conclusions}

The mathematical models (24), (25), (26) and (27) obtained from the experiments were the experimental statistical models which could well describe the impact of temperature of moisture condensation, temperature of cold drying chamber, velocity air or drying agents and time of cold drying process on the energy consumption per weight, the residual water content, the anti-rehydration capacity, and the loss of total $\beta$-carotene and lycopene in Gac of the cold-dried product.

Solving multi-objective optimization problem by the restricted area method determined the optimal technological mode of cold drying process of $\mathrm{Gac}$, with temperature of moisture condensation of $9.83^{\circ} \mathrm{C}$, temperature of cold drying chamber of $44.18^{\circ} \mathrm{C}$, the velocity drying agents of $3.46 \mathrm{~m} / \mathrm{s}$ and the time of cold drying process of $12.36 \mathrm{~h}$, resulting in: the energy consumption per weight of the colddried product of $2.09 \mathrm{kWh} / \mathrm{kg}$; the residual water content of the cold-dried product of $7.86 \%$; the anti-rehydration capacity of the cold-dried product of $8.997 \%$ (or rehydration capacity of the cold-dried product of $91.003 \%$ ) and the loss of total $\beta$-carotene and lycopene in Gac of the cold-dried product of $5.07 \%$.

Therefore, the technological mode of cold drying process of Gac was feasible to be applied to industrial production.

\section{References}

Anh Le, Sophie Parks, Minh Nguyen, Paul Roach, (2018). Optimisation of the Microwave-Assisted Ethanol Extraction of Saponins from Gac (Momordica cochinchinensisSpreng.)Seeds. Medicines 2 018, 5 (3),70.DOI: 10.3390/medicines50300 70.

Anh V. Le, Sophie E. Parks, Minh H. Nguyen, Paul D. Roach, (2018). Physicochemical Properties of Gac (Momordica cochinchinensis (Lour.) Spreng) Seeds and Their Oil Extracted by Supercritical Carbon Dioxide and Soxhlet Methods. Technologies 2018, 6 (4), 94. DOI: 10.3390/technologies6040094.

Apinya Bhumsaidon, Montip Chamchong, (2016). Variation of lycopene and betacarotene contents after harvesting of gac fruit and its prediction. Agriculture and Natural Resources, 2016, 50 (4) , 257-263. DOI: 10.1016/j.anres.2016.04.003.

Betty K. Ishida, et al., (2004). Fatty Acid and Carotenoid Composition of Gac (Momordica cochinchinensis Spreng) Fruit. Journal of Agriculture and Food 
Chemistry. 52, 2, 274-279. https://doi.org/10.1021/jf030616i

Chai, A. L., Zhao, Q., Li, B. J., Sinsiri, W., (2018). First Report of Anthracnose Caused by Colletotrichum brevisporum on $\mathrm{Gac}$ (Momordica cochinchinensis) in Thailand Plant Disease, 2018, 102 (11) , 2378-2378. DOI: 10.1094/PDIS-04-18-0674-PDN.

Heldman, D. R., Daryl, B. Lund, (1992). Handbook of Food Engineering, Marcel Dekker New York - Basel - Hong Kong 1992, $3550 \mathrm{p}$

Dzung N.T, et al., (2016a). The Multi-objective Optimization by the Restricted Area Method to Determine the Technological Mode of Cold Drying Process of Carrot Product. Research Journal of Applied Sciences, Engineering and Technology, 13 (1), 64-74

Dzung, N.T, (2016c). Study of determining the technological mode in the freeze drying process of royal jelly in viet nam. Carpathian Journal of Food Science \& Technology, 8 (2).

Dzung, N.T, (2018c). Study the heat transfer model in the freezing process of basa sausage in vietnam to determine the technological mode. Carpathian Journal of Food Science \& Technology, 10 (2)

Dzung, N.T, et al., (2011). Application of multi-objective optimization to determining the technological mode of avocado oil extraction. Canadian Journal on Chemical Engineering and Technology, 2 (6), 19231952.

Dzung, N.T, et al., (2016b). The Multiobjective Optimization by the Utopian Point Method to Determine the Technological Mode of Infrared Radiation Drying Process of Jackfruit Product in Viet Nam. Research Journal of Applied Sciences, Engineering and Technology, 13 (1), 75-84.

Dzung, N.T, et al., (2018a). Modeling the freezing process of turmeric starch to determine the rate of freezing water. Recent Advances in Food Science, 1 (1), 32-41.
Dzung, N.T, et al., (2018b). Study the loss of 10-HDA inside royal jelly in vietnam for the freeze-drying process. , 1 (2), 97-105.

Figura, L.O., Teixeira, A.A. (2007). Food Physics: Physical properties Measurement and Application, Germany, 554. http:// mechmath.org/books /82246

Fortes, M., et al., (1999),. Heat and mass transfer analysis of intra-kernal wheat drying and reweting. Journal of Agricultural Engineering Research. 26, 109-125.

Gebhart, B., (1992). Heat Conduction and Mass Diffusion, McGraw - Hill, New York.

Haugvalstad, G.H., Skipnes.D., Sivertsvik.M, (2005). Food free from preservative, Journal of Food Engineering.

Holman, J., (1992). Heat Transfer, McGraw Hill, New York.

Khalloufi, S., Robert, J. L., and Ratti, (2004). Solid foods Freeze drying simulation and experimental data, Journal of Food Engineering, Canada 28: 107-132. DOI: 10.1111/j.1745-4530.2005.00379.x

Luikov, A.V., (1975). Systems of differential equations of heat and mass transfer in capillary-porous bodies. International Journal of Heat and mass transfer.

Vaccarezza, L.M., Lombardi, J.L., and Chirife, J., (1994). Kinetics of moisture movement during air drying of suger beet root. Food Technolology, 9,317

\section{Acknowledgments}

The author thanks Head of Lab Food Engineering and Technology, Department of Food Technology, Faculty of Chemical and Food Technology, HCMC University of Technology and Education, Vietnam, for help with experiments carried out. 